\title{
The Proportion of Shares Held by the Largest Shareholder and the Proportion of Independent Directors
}

\author{
Xiaopeng Chu \\ Henley Business School, University of Reading, Reading, UK \\ Email: 237938355@qq.com
}

How to cite this paper: Chu, X. P. (2021). The Proportion of Shares Held by the Largest Shareholder and the Proportion of Independent Directors. Open Journal of Business and Management, 9, 761-774. https://doi.org/10.4236/ojbm.2021.92040

Received: February 22, 2021

Accepted: March 26, 2021

Published: March 29, 2021

Copyright $\odot 2021$ by author(s) and Scientific Research Publishing Inc. This work is licensed under the Creative Commons Attribution International License (CC BY 4.0).

http://creativecommons.org/licenses/by/4.0/

\begin{abstract}
In this paper, the relevant data of the proportions of major shareholders and independent directors from 2008 to 2017 are examined. Firstly, the functions of the board of directors and the role of independent directors are introduced. Then, the impact of the institutional changes of the board of directors on the proportion of independent directors is investigated. Next, the determinants of the structure of the board of directors are reviewed. Thus, two hypotheses are proposed. According to the regression results of the model, hypothesis $1 \mathrm{~B}$ presents positive significance. It can be concluded through the influence of the largest shareholder's shareholding ratio on the proportion of independent directors in the board of directors that the higher the shareholding ratio of the largest shareholder, the higher the proportion of independent directors. By increasing the proportion of independent directors, the voting space of non-independent directors will be squeezed, so as to increase their control. This study reveals that the ownership structure is an essential factor influencing the structure of the board of directors, constituting a crucial supplement to the literature on the determinants of the structure of the board of directors.
\end{abstract}

\section{Keywords}

Major Shareholder, Largest Shareholder, Independent Directors, Structure of the Board of Directors, Shareholding Ratio

\section{Introduction}

There are considerable studies on the proportions of the largest shareholder and independent directors, respectively, from the influence of CEO, supervision costs and benefits, and the company's business scope (Hermalin \& Weisbach, 1998; Arthur, 2001; Boone et al., 2007). Besides, there is a small amount of re- 
search on the Chinese market. This article is based on a new perspective. In the selected time period, it excludes both the influence of the reform of non-tradable shares and the influence of the unification of the system in 2003. Additionally, the influence on the shareholding ratio of the largest shareholder is investigated in combination with the unique situation of one share dominance in China.

How to maximize their own interests is the problem that every shareholder considers. The appointment of directors and the establishment of a board of directors are common approaches for shareholders to protect their own interests (Bebchuk \& Weisbach, 2010). The board of directors is not only the decision-making body of the company's operation but also the permanent authority of the shareholders. It is responsible for the shareholders to supervise the operation of the company on behalf of the shareholders. The functions of the directors and the board of directors are mainly embodied in covering the general meeting of shareholders, reporting to the general meeting of shareholders, implementing the resolutions of the general meeting of shareholders, deciding on the company's business plan and investment plan, and deciding on the establishment of the company's internal management organization and formulating the company's basic management system.

Given that the directors and the board of directors are very important in the company, they have become the main goal of corporate governance (Fama \& Jensen, 1983). Since the rights of directors and the board of directors are second only to shareholders, China's listed companies appoint independent directors to strengthen their management to ensure that directors or shareholders do not abuse their powers and perform their supervisory duties better. The role of an independent director is to objectively supervise the management, safeguard the rights and interests of small and medium shareholders, and prevent insider control. Most of the independent directors are celebrities, contributing to enhancing the company's image and facilitating market financing. Independent directors have the obligation of honesty and diligence to the listed company and all shareholders. In accordance with the requirements of relevant laws, regulations, guidance, and articles of association responsibility, they should conscientiously perform their duties and safeguard the overall interests of the company. In China's independent director system, the independent director of a listed company does not hold any position other than a director in the company and has no relationship with the listed company and its major shareholders that may hinder his independent and objective judgment. In principle, independent directors can concurrently serve as independent directors in up to five listed companies and ensure that they have enough time and energy to effectively perform their duties.

The system of an independent board of directors in China began in 2001. Before 2001, listed companies in China could decide whether to set up independent directors. Consistent with the original intention of improving the governance structure of listed companies and promoting the standardized operation of listed 
companies, China Securities Regulatory Commission issued the guiding opinions on the establishment of an independent director system in listed companies on August 16, 2001 (CSRC law [2001] No. 102). The guiding opinions require domestic listed companies to employ appropriate personnel as independent directors. Before June 30, 2006, the board of directors should include at least two independent directors; before June 30, 2003, the board of directors of listed companies should include at least one third of independent directors.

In Figure 1, the changes in the shareholding ratio of the largest shareholder and the proportion of independent directors in many Chinese listed companies from 1999 to 2017 are synthesized. It can be observed that the emergence of independent directors has significantly inhibited the shareholding ratio of the largest shareholder before 2003. However, this phenomenon has become flat and almost no longer affected the shareholding ratio of the largest shareholder since the emergence of the new system in 2003. Therefore, independent directors would not play their functions. It can be clearly seen from Figure 1 that from 2006 to 2013, the proportion of independent directors and the shareholding proportion of the largest shareholder were relatively flat. However, from 2014 to 2017, it is obvious that the proportion curve of independent directors is higher than that of the largest shareholder, thus, it needs further study, which is discussed in this article later.

Figure 2 is the same as the Chinese listed companies synthesized in Figure 1, recording the changes in the shareholding ratio of the largest shareholder and the size of the board of directors from 1999 to 2017. It reveals that the size of the board of directors before 2001 significantly decreased while the size after 2001 exhibited a short rise due to the formation of the new system. After 2003, the size of the board of directors has an apparent downward trend. However, the proportion of shares held by the largest shareholder gently declined. Therefore, there may be a correlation between the two, which needs further investigation.

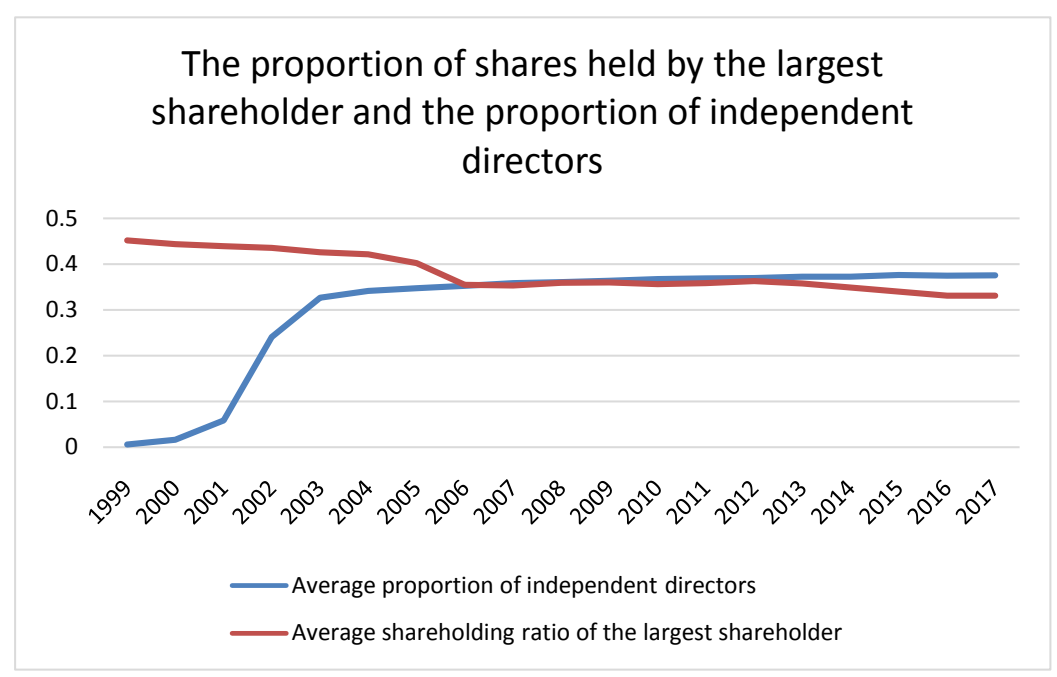

Figure 1. The proportion of shares held by the largest shareholder and the proportion of independent directors. 


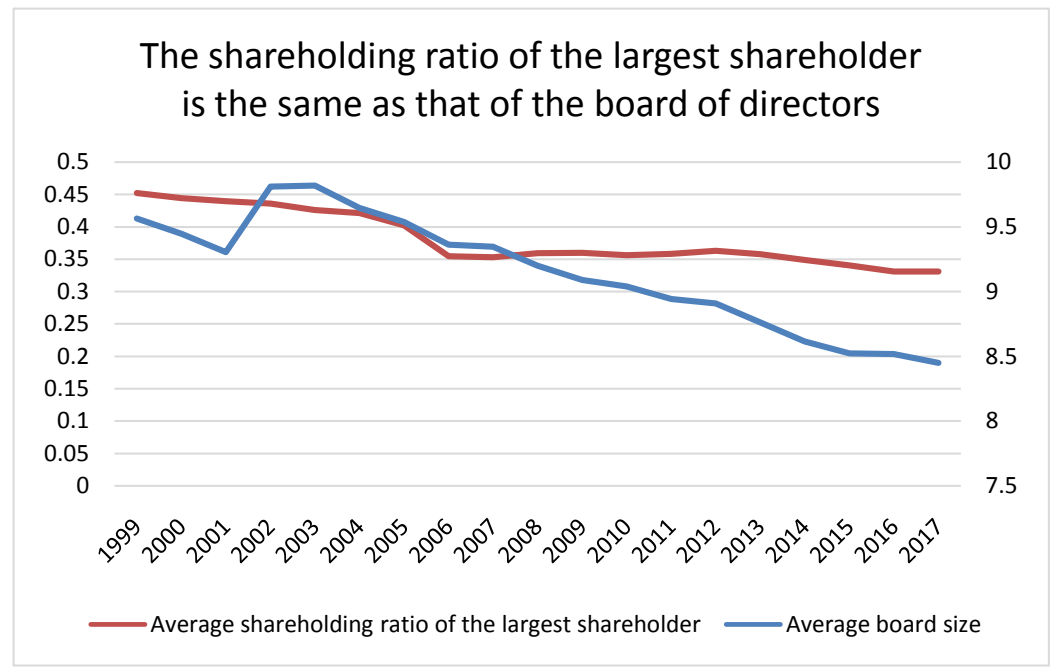

Figure 2. The shareholding ratio of the largest shareholder is the same as that of the board of directors.

This paper takes the independent director as the dependent variable and the shareholding ratio of the largest shareholder as the independent variable. The factors such as company size, enterprise value, cash flow ratio, asset-liability ratio, and property right nature are taken as control variables. Besides, the term of office of the director may be the same as that of the independent director in the previous annual report during the period of $3-5$ years. Therefore, the data of realization is still very stable, though it is added into the control variable. The data of board structure, corporate characteristics, and governance characteristics are all from the CSMAR database, and some missing data are manually supplemented by the wind database. Through the influence of the largest shareholder's shareholding ratio on the proportion of independent directors in the board of directors, this paper concludes that the higher the shareholding ratio of the largest shareholder, the higher the proportion of independent directors. By increasing the proportion of independent directors, the voting space of non-independent directors will be squeezed to increase their control. This study indicates that the ownership structure is an essential factor influencing the structure of the board of directors, constituting an important supplement to the literature on the determinants of the structure of the board of directors.

The rest of the paper will be divided into Section 2 literature review, Section 3 hypothesis development, Section 4 data, Section 5 regression results, and Section 6 conclusion.

\section{Literature Review}

An enterprise must include shareholders, the board of directors, and managers, which will cause agency problems. The summary of such problems by Jensen \& Meckling (1976) and Villalonga \& Amit (2006) reveals two different agency problems. 1) The ownership of shareholders in the company is decentralized. 
Thus, there is no enough energy to supervise the managers. Besides, managers would make decisions optimal for themselves because they are self-interested. 2) When a company has large shareholders, the ownership is relatively concentrated, and the dominant shareholders are selfish and make decisions against minority shareholders. Due to the phenomenon of "one share dominates" is obvious, the latter generally appears in the listed companies in China.

Therefore, the directors of the company set up independent directors to strengthen supervision. Many articles have studied the determinants of board structure. Generally, there are three points: CEO's influence, monitoring costs and benefits, and the scope of the company's business.

Weisbach (1988) proposed that CEO turnover and performance indicators are higher in the companies with external directors leading the board of directors compared to the companies with insiders leading the board of directors. Therefore, external directors tend to replace CEOs to improve corporate income and increase corporate value. Hermalin and Weisbach (1998) demonstrated that the structure of the board of directors depends on the negotiation process between the CEO and the existing board of directors. This conclusion is illustrated by the process of the acquisition of the big board of directors by automobile companies, suggesting that CEO turnover is negatively correlated with performance. The more independent the board of directors, the more obvious the phenomenon. In 2001, Arthur N. summarized these phenomena and concluded that CEO tenure and internal ownership play a vital role in the decision of board composition. With the increasing CEO's tenure, their rights will be greatly improved, and their influence on the board of directors will be strengthened. In this way, they will be less supervised by independent directors, and their remuneration will help them avoid risks.

Boone et al. (2007) proposed that companies with more experience, larger scale, and higher degree of diversification have larger and more independent board of directors. The more power and influence managers have, the less independent directors they have. Therefore, the size and independence of the board of directors are formed by the combination of company management characteristics and special policies. Besides, Iwasaki I. researched Russian business management and investors' monitoring and supervision system in 2008 by describing their business management and investors. In Russia, the board of directors is full of negative phenomena, and the major shareholders seek to maximize their rights. After the independent director joins again, the expected results were not produced. Therefore, starting from the supervision function of independent directors, the size and structure of the board of directors for the cost and benefit of supervision are closely related to the needs of its supervision business activities. Linck, Netter, \& Yang confirmed this conclusion in their research in 2008 and mentioned that the powerful managers in the company would build the board of directors more favorably. Moreover, there will be more independent directors when the insiders have the opportunity to obtain private interests. 
The organizational form is closely related to the business scope and complexity of a company. Denis and Sarin (1999) established a model to analyze the data and discovered that the substantial changes of ownership and board structure are related. Before significant changes in ownership and director structure, this correlation will fundamentally change, followed by large-scale asset restructuring.

Besides, many people have studied the board of directors in China and obtained relevant empirical evidence due to the special situation of China's dominance. Xiao Weijia, Wang Zhengwei, and Duan Yun (2009) revealed that the proportion of independent directors does not affect the company's performance. When there are large shareholders, they will use all means to maximize their own interests, such as controlling the independent directors by controlling the board of directors of the company. Liu Hao, Tang Song, and Lou Jun (2012) conducted a study on independent directors with bank background and revealed that after having independent directors with bank background, the company's credit financing has been improved while the importance of supervision has not been highlighted. The supervision function of independent directors has been dramatically reduced due to the dominance of one share. Additionally, Wang Bing (2007) analyzed the independent directors with an accounting background, demonstrating that the independent directors can play a limited supervisory role. In other words, the supervision function of independent directors cannot play its due role because the rights of major shareholders are too high. For China's unique dominance, the determinants of board structure have also changed. Regarding the influence of the CEO and the existence of large shareholders, it is difficult for independent directors to exert their supervisory functions, making the substantive role of independent directors negligible.

\section{Hypothesis Development}

The most fundamental characteristics of independent directors are independence and professionalism. There is no relationship with the company's internal personnel that may hinder their independent judgment. They can always maintain a neutral attitude and supervise other members of the board of directors and managers, enabling all stakeholders to maximize their interests in a fair and just situation. Previous studies have focused on the impact of CEO influence or supervision cost on the structure of independent directors. However, there is little research on its impact on the structure of independent directors combined with the unique phenomenon of China's one share dominance. "One share dominates" is a natural response to the lack of legal protection of investors' rights (Allen et al., 2005). In the special case of one share dominating, there are significant differences in the distribution of rights. Therefore, the executive rights of small shareholders cannot compete with large shareholders, and the supervision direction of large shareholders to managers is more inclined to maximize their own interests. This is very unfavorable to small shareholders. In the competition of control rights, the market value of voting rights and the expected return of 
shareholders can reflect the impact of the special phenomenon of dominance on the enterprise environment (Lease, McConnell, \& Mikkelson, 1983; Dann \& Mikkelson, 1984).

When the independent directors of a company can play their supervisory functions, they can vote against the proposals that may damage the interests of the major shareholders (Jiang et al., 2010) to protect the interests of the minor shareholders. Such an approach can also warn investors, urge regulators to supervise them, and improve corporate governance (Zheng, Hu, \& Huang, 2019). Therefore, large shareholders use a "pyramid structure" to control some enterprises, so as to avoid being supervised. Then, the large shareholders conduct "tunneling behavior" to transfer the company's resources through an asset sale, transfer pricing contract, cash misappropriation, and other related transactions under the control chain. Consequently, they can obtain more private rights to suppress the small shareholders and obtain more benefits. Glaeser and Shleifer (2001) proposed that tunneling is a chain of transferring resources through internal transactions, like a tunnel, which continuously transports the resources of enterprises at the bottom of the pyramid to the ultimate owners at the top of the pyramid. Moreover, large shareholders can also maximize their own interests through cross-shareholding. Based on a "pyramid" or horizontal structure, the controlled enterprise owns the shares of the upstream enterprise of its control chain simultaneously, forming another control chain to obtain more rights. Thus, we put forward the first hypothesis.

Hypothesis 1A: Assuming that if independent directors can play a supervisory role, large shareholders will reduce the proportion of independent directors for their own interests and avoid constraints.

On the contrary, when the company's independent directors cannot play a supervisory role, there will be a "vase" phenomenon of independent directors. Large shareholders may squeeze the space of non-controlling shareholders' directors through independent directors, making it easier for them to pass proposals beneficial to their own interests. Although independent directors need to maintain an independent relationship with listed companies and their shareholders in the system, large shareholders play an important role in the nomination process of directors in practice. The majority shareholders have more voting rights than the minority shareholders. Therefore, in the election of independent directors, the majority shareholders can use their rights to vote against the nomination of independent directors who may be unfavorable to them in the future. Moreover, the majority shareholders have the right to vote in the final shareholders' meeting to influence the selection of independent directors, even without considering the impact of the nomination process. In the end, the independent directors who can be elected by the general meeting will be beneficial to the majority shareholders. Besides, the independent directors vote against the major shareholders at the general meeting of shareholders, and the major shareholders can use their own rights to remove them. For example, in China's 
listed company "Tianmu pharmaceutical company", two independent directors were later proposed to be removed because they cast a negative vote to restrict the majority shareholders. The majority shareholders hold a large proportion of shares due to the implementation of the one share one vote capital majority principle at the general meeting of shareholders, causing the independent directors to be removed. In 2019, Zheng Zhigang, Hu Xiaoji, and Huang Chengji proposed that the board of directors is the core of corporate governance; nonetheless, the over appointment of directors indicates that the major shareholders have greater influence in the voting of the relevant bills on the board of directors, enabling them to easily pass the bills beneficial to themselves; then, independent directors, as "vases", will not say "no" according to their supervision functions. Therefore, we propose the second hypothesis.

Hypothesis 1B: Assuming that the independent directors only play the role of vase and cannot play their functions independently, then the large shareholders may squeeze the space of the non-controlling shareholders' directors through the independent directors, making it easier to pass the proposals beneficial to their own interests.

\section{Data}

Referring to the relevant literature (Boone et al., 2007; Linck et al., 2008), the regression model set by the following formula (1) is used in this study to examine the possible impact of the shareholding ratio of the largest shareholder on the appointment of independent directors and test hypothesis 1. Using the following formula to calculate the data obtained through the influence of different control variables, hypothesis $1 \mathrm{~B}$ is verified if the result is positive significant, and hypothesis $1 \mathrm{~A}$ is verified if the result is negative significant.

$$
\begin{aligned}
& \text { Independence }_{i, t} \\
& =\alpha+\beta_{1} \operatorname{Top}_{i, t} / Z 10_{i, t}+\sum \text { Control Variables } \\
& i, t \\
& + \text { Industry }_{i, t}+\text { Year }_{i, t}+\epsilon_{i, t}
\end{aligned}
$$

The data of board structure, corporate characteristics, and governance characteristics are all from the CSMAR database, and some missing data are manually supplemented by the wind database. The data sample range is 2008-2017. CSMAR database is a set of authoritative and accurate financial database. It is a series of high-level professional financial, financial and Economic Databases designed and developed by Guotai'an Company for the needs of China's financial and economic analysis and research by experts and scholars from institutions of higher learning, financial and securities institutions and social research institutions. Wind database is the largest, most complete and most widely used financial database with securities as the core in China.

Table 1 showed that we take the proportion of independent directors as the dependent variable and the proportion of shareholders as the independent variable. The factors such as company size, asset-liability ratio, free cash flow ratio, and the size of the board of supervisors are taken as control variables. Then, the calculation results are obtained through the model proposed in this paper. 
Table 1. Variables.

\begin{tabular}{|c|c|c|}
\hline Variable meaning & Variable name & Variable calculation method \\
\hline \multicolumn{3}{|l|}{ Panel A: Explained variable } \\
\hline Proportion of independent directors & Independence & Number of independent directors/board of directors \\
\hline \multicolumn{3}{|l|}{ Panel B: Main explanatory variables } \\
\hline Ownership concentration & Top 1 & Shareholding ratio of the largest shareholder \\
\hline Equity balance & $Z 10$ & $\begin{array}{l}\text { The shareholding ratio of the largest shareholder/the shareholding } \\
\text { ratio of two to ten shareholders, and the logarithm of the ratio value }\end{array}$ \\
\hline \multicolumn{3}{|l|}{ Panel C: Main control variables } \\
\hline Company size & Size & Logarithm of total assets of the company \\
\hline Asset liability ratio & Leverage & Total liabilities/total assets of the company \\
\hline Company growth capability & Growth & The growth rate of the company's operating revenue \\
\hline Profit margin of company assets & Roa & Net profit/total assets \\
\hline Size of the board of supervisors & Supsize & The number of the board of supervisors is taken as the logarithm \\
\hline Two jobs at the same time & Duality & $\begin{array}{l}\text { The dummy variable is } 1 \text { when the chairman of the board concurrently } \\
\text { serves as the general manager, otherwise, it is } 0\end{array}$ \\
\hline $\begin{array}{l}\text { Shareholding ratio of senior execu- } \\
\text { tives }\end{array}$ & Excuratio & Number of shares held by senior executives/total equity \\
\hline Enterprise value & TobinQ & Market value/book value of the company \\
\hline Company age & Firmage & $\begin{array}{l}\text { Financial reporting year-the year of the company's listing, and take the } \\
\text { logarithm }\end{array}$ \\
\hline Free cash flow ratio & Fcf & $\begin{array}{l}\text { (earnings before interest and tax }+ \text { depreciation and amortization- } \\
\text { increase in working capital-capital expenditure)/total assets }\end{array}$ \\
\hline CEO tenure & CEO_tenure & Take the logarithm of the CEO's tenure \\
\hline Stock Volatility & Retstd & Volatility of monthly stock returns over 12 months \\
\hline Nature of property rights & State & If the controlling shareholder is state-owned, it is 1 , otherwise, it is 0 \\
\hline $\begin{array}{l}\text { Does the company deal with it in that } \\
\text { year }\end{array}$ & $S T$ & $\begin{array}{l}\text { The dummy variable is } 1 \text { when the company specially processes it in that } \\
\text { year, otherwise, it is } 0\end{array}$ \\
\hline Industry fixed effect & Industry & Industry dummy variable \\
\hline Year fixed effect & Year & Year dummy variable \\
\hline
\end{tabular}

\section{Results}

1) Descriptive statistical results:

In Table 2, the average proportion of independent directors is 0.3719 , suggesting that the proportion of independent directors in the board of directors of each company is concentrated in one third on average. However, the standard deviation is 0.0529 , the maximum is 0.5714 , and the minimum is 0.3077 , indicating significant differences in the proportion of independent directors in different companies. The average proportion of top 1 in each company is 0.3486 , demonstrating the apparent phenomenon of one share dominating. Besides, the average value of $\mathrm{Z10}$ is greater than one, implying that the relative power of the largest shareholder is extremely strong. 
Table 2. Data about variables.

\begin{tabular}{|c|c|c|c|c|c|c|}
\hline Variable name & Number of samples & Mean value & Standard deviation & Minimum value & Maximum value & Median value \\
\hline Independence & 20,865 & 0.3719 & 0.0529 & 0.3077 & 0.5714 & 0.3333 \\
\hline Top 1 & 20,865 & 0.3486 & 0.1499 & 0.0898 & 0.75 & 0.3283 \\
\hline$Z 10$ & 20,865 & 1.1461 & 0.7099 & 0.2403 & 4.1088 & 0.9376 \\
\hline Size & 20,865 & 21.9765 & 1.2783 & 19.1197 & 25.6956 & 21.8231 \\
\hline Leverage & 20,865 & 0.4475 & 0.2198 & 0.0563 & 1.0884 & 0.4417 \\
\hline Growth & 20,865 & 0.2147 & 0.5631 & -0.675 & 3.936 & 0.117 \\
\hline Roa & 20,865 & 0.0359 & 0.0602 & -0.3151 & 0.1913 & 0.0347 \\
\hline Supsize & 20,865 & 1.5128 & 0.2112 & 1.0986 & 2.1972 & 1.3863 \\
\hline Duality & 20,865 & 0.2395 & 0.4268 & 0 & 1 & 0 \\
\hline Excuratio & 20,865 & 0.058 & 0.1277 & 0 & 0.5694 & 0.0001 \\
\hline TobinQ & 20,865 & 2.5925 & 1.8864 & 0.8392 & 11.3523 & 1.982 \\
\hline Firmage & 20,865 & 2.1388 & 0.7739 & 0 & 3.2189 & 2.3026 \\
\hline$F c f$ & 20,865 & -0.0042 & 0.1193 & -0.5072 & 0.2927 & 0.0145 \\
\hline CEO_tenture & 20,865 & 3.4147 & 0.996 & 0 & 5.0434 & 3.4965 \\
\hline Retstd & 20,865 & 0.1374 & 0.0627 & 0.0442 & 0.3794 & 0.1239 \\
\hline State & 20,865 & 0.3662 & 0.4818 & 0 & 1 & 0 \\
\hline$S T$ & 20,865 & 0.0358 & 0.1857 & 0 & 1 & 0 \\
\hline
\end{tabular}

2) Regression results:

In this paper, the treatment effect model is employed to control the shareholding ratio of the largest shareholder. In Table 3, the first three models take the Top1 template as an independent variable, and the last three models take $\mathrm{Z} 10$ as an independent variable. Model 1 and model 4 are data without control variables. Model 2 and model 5 are added with the data of control variables. Model 3 and Model 6 are the data obtained by adding the proportion of independent directors in the previous period as the control variable based on the addition of control variables.

As illustrated in the regression results, the result in model 1 presents a positive trend when Top 1 is used as the independent variable, indicating that the higher the proportion of the largest shareholder, the higher the proportion of independent directors in the company. With control variables, our data is very stable, exhibiting a positive significance. Since the term of office of an independent director is 3 - 5 years, the proportion of the same independent director in the last term may be the same, which is continuous. Therefore, this is added to control variables. Regardless of the addition of this control variable, our results are still stable. When Z10 is used as the independent variable, models 4, 5, and 6 also show positive significance. The data of control variables reveal that the size of the company is positively significant under two different independent variables, and the leverage of the company is negatively significant. Besides, the coefficient 
Table 3. Data for variables in different models.

\begin{tabular}{|c|c|c|c|c|c|c|}
\hline & Model 1 & Model 2 & Model 3 & Model 4 & Model 5 & Model 6 \\
\hline VARIABLES & \multicolumn{6}{|c|}{ Independence } \\
\hline \multirow[t]{2}{*}{ Top1 } & $0.0206^{* * *}$ & $0.0215^{\star * *}$ & $0.0052^{* *}$ & & & \\
\hline & $(3.5582)$ & $(3.6359)$ & $(2.5562)$ & & & \\
\hline \multirow[t]{2}{*}{$Z 10$} & & & & $0.0027^{\star *}$ & $0.0041^{\star * *}$ & $0.0011^{* * *}$ \\
\hline & & & & $(2.3241)$ & $(3.4224)$ & $(2.7739)$ \\
\hline \multirow[t]{2}{*}{ L.Independence } & & & $0.7445^{\star * \star}$ & & & $0.7445^{* * *}$ \\
\hline & & & (87.3618) & & & $(87.4653)$ \\
\hline \multirow[t]{2}{*}{ Size } & & $0.0042^{\star * *}$ & $0.0010^{* * *}$ & & $0.0048^{\star * *}$ & $0.0012^{\star * *}$ \\
\hline & & $(4.1000)$ & $(2.9872)$ & & $(4.7173)$ & (3.4409) \\
\hline \multirow[t]{2}{*}{ Leverage } & & $-0.0082^{\star \star}$ & -0.0024 & & $-0.0087^{\star *}$ & -0.0025 \\
\hline & & $(-1.9907)$ & $(-1.4403)$ & & $(-2.0987)$ & $(-1.4999)$ \\
\hline \multirow[t]{2}{*}{ Growth } & & -0.0001 & -0.0006 & & 0.0002 & -0.0005 \\
\hline & & $(-0.0864)$ & $(-0.8992)$ & & $(0.2958)$ & $(-0.8021)$ \\
\hline \multirow[t]{2}{*}{ Roa } & & $-0.0496^{\star * *}$ & $-0.0137^{\star *}$ & & $-0.0462^{\star * *}$ & $-0.0127^{* *}$ \\
\hline & & $(-4.8244)$ & $(-2.2151)$ & & $(-4.4914)$ & $(-2.0728)$ \\
\hline \multirow[t]{2}{*}{ Supsize } & & $-0.0206^{* * *}$ & $-0.0062^{\star * *}$ & & $-0.0205^{\star * *}$ & $-0.0061^{* * *}$ \\
\hline & & $(-5.0856)$ & $(-4.3097)$ & & $(-5.0617)$ & $(-4.2809)$ \\
\hline \multirow[t]{2}{*}{ Duality } & & $0.0079^{* * *}$ & $0.0031^{\star * \star}$ & & $0.0079^{\star * *}$ & $0.0031^{\star * *}$ \\
\hline & & $(4.0264)$ & (3.9303) & & $(4.0360)$ & (3.9206) \\
\hline \multirow[t]{2}{*}{ Excuratio } & & $0.0248^{* * *}$ & 0.0024 & & $0.0252^{\star * *}$ & 0.0026 \\
\hline & & $(3.1365)$ & $(0.8038)$ & & $(3.1825)$ & $(0.8650)$ \\
\hline \multirow[t]{2}{*}{ TobinQ } & & $0.0027^{* * *}$ & $0.0007^{* * *}$ & & $0.0029^{* * *}$ & $0.0007^{* * *}$ \\
\hline & & $(5.8936)$ & $(3.2793)$ & & $(6.2569)$ & $(3.5109)$ \\
\hline \multirow[t]{2}{*}{ Firmage } & & 0.0012 & -0.0004 & & -0.0003 & -0.0008 \\
\hline & & $(1.0118)$ & $(-0.7741)$ & & $(-0.2274)$ & $(-1.5558)$ \\
\hline \multirow[t]{2}{*}{ Fcf } & & 0.0043 & $0.0046^{*}$ & & 0.0042 & $0.0044^{\star}$ \\
\hline & & (1.4016) & (1.7903) & & (1.3496) & $(1.7160)$ \\
\hline \multirow[t]{2}{*}{ CEO_tenture } & & -0.0006 & 0.0005 & & -0.0007 & 0.0005 \\
\hline & & $(-1.0644)$ & $(1.6267)$ & & $(-1.2031)$ & $(1.5567)$ \\
\hline \multirow[t]{2}{*}{ Retstd } & & 0.0042 & 0.0033 & & 0.0027 & 0.0029 \\
\hline & & $(0.4830)$ & $(0.5207)$ & & $(0.3163)$ & $(0.4605)$ \\
\hline \multirow[t]{2}{*}{ State } & & -0.0001 & -0.0000 & & 0.0001 & -0.0000 \\
\hline & & $(-0.0431)$ & $(-0.0369)$ & & $(0.0611)$ & $(-0.0112)$ \\
\hline \multirow[t]{2}{*}{$S T$} & & $0.0052^{\star}$ & $0.0042^{\star *}$ & & $0.0054^{*}$ & $0.0042^{* *}$ \\
\hline & & $(1.7777)$ & $(2.1820)$ & & (1.8705) & $(2.2015)$ \\
\hline \multirow[t]{2}{*}{ Constant term } & $0.3617^{* * *}$ & $0.3004^{* * *}$ & $0.0832^{\star * *}$ & $0.3653^{* * *}$ & $0.2929^{* * *}$ & $0.0811^{\star * *}$ \\
\hline & $(45.3859)$ & $(13.4347)$ & (9.9028) & $(46.1815)$ & $(13.0405)$ & $(9.6268)$ \\
\hline Year fixed effect & Control & Control & Control & Control & Control & Control \\
\hline Industry fixed effect & Control & Control & Control & Control & Control & Control \\
\hline Number of samples & 20,865 & 20,865 & 17,449 & 20,865 & 20,865 & 17,449 \\
\hline Adjust $R^{2}$ & 0.0315 & 0.0541 & 0.5752 & 0.0296 & 0.0535 & 0.5753 \\
\hline
\end{tabular}


of the key explanatory variable of our regression results is positive, and the significance is $1 \%$. Therefore, the higher the proportion of the largest shareholder, the higher the proportion of independent directors in the board of directors. Thus, hypothesis $1 \mathrm{~B}$ has been confirmed. Furthermore, the largest shareholder has a lot of real power under the phenomenon of one share dominating in China. Therefore, in the election of independent directors, we should choose those who are beneficial to us and suppress minority shareholders through the supervision function or other functions of independent directors to maximize our own interests.

\section{Conclusion}

In this paper, the interaction between the proportion of major shareholders and the proportion of independent directors from 2008 to 2017 is explored. Based on the unique phenomenon of "one share dominating" of Chinese listed companies, the influence of the change of independent director system on the proportion of independent directors and the proportion of major shareholders is investigated. Then, the determinants of board structure are revealed: the influence of the CEO, the cost and benefit of supervision, and the scope of the company's business. On this basis, relevant empirical evidence from China is added. Thus, two hypotheses are proposed. Starting from the function of independent directors and the practice of selecting and appointing directors, the relationship between the shareholding ratio of the largest shareholder and the proportion of independent directors is verified. The empirical results demonstrate that the higher the proportion of the largest shareholder, the higher the proportion of independent directors.

This study indicates that the ownership structure is an essential factor influencing the structure of the board of directors, constituting a crucial supplement to the literature on the determinants of the structure of the board of directors. This result significantly contributes to the governance of Listed Companies in China. As revealed by comparing the shareholding ratio of major shareholders and the proportion of independent directors, the phenomenon of "vase" of independent directors in China's listed companies is significant. Therefore, it can inspire research on the change of the corporate governance system in the future. However, this paper also has shortcomings. Due to the updating of the database, this paper does not include the data of 2018-2020. Therefore, it may lead to the conclusion of this paper inconsistent with the current situation.

\section{Conflicts of Interest}

The author declares no conflicts of interest regarding the publication of this paper.

\section{References}

Allen, F., Qian, J., \& Qian, M. J. (2005). Law, Finance, and Economic Growth in China. 
Journal of Financial Economics, 77, 57-116.

https://doi.org/10.1016/j.jfineco.2004.06.010

Arthur, N. (2001). Board Composition as the Outcome of an Internal Bargaining Process: Empirical Evidence. Journal of Corporate Finance, 7, 307-340.

https://doi.org/10.1016/S0929-1199(01)00024-4

Bebchuk, L. A., \& Weisbach, M. S. (2010). The State of Corporate Governance Research. Review of Financial Studies, 23, 939-961. https://doi.org/10.1093/rfs/hhp121

Boone, A. L., Field, L. C., Karpoff, J. M., \& Raheja, C. G. (2007). The Determinants of Corporate Board Size and Composition: An Empirical Analysis. Journal of Financial Economics, 85, 66-101. https://doi.org/10.1016/j.jfineco.2006.05.004

Dann, L. Y., \& Mikkelson, W. H. (1984). Convertible Debt Issuance, Capital Structure Change and Financing-Related Information: Some New Evidence. Journal of Financial Economics, 13, 157-186. https://doi.org/10.1016/0304-405X(84)90022-9

Denis, D. J., \& Sarin, A. (1999). Ownership and Board Structures in Publicly Traded Corporations. Journal of Financial Economics, 52, 187-223.

https://doi.org/10.1016/S0304-405X(99)00008-2

Fama, E. F., \& Jensen, M. C. (1983). Separation of Ownership and Control. Journal of Law and Economics, 26, 301-325. https://doi.org/10.1086/467037

Glaeser, E. L., \& Shleifer, A. (2001). Not-for-Profit Entrepreneurs. Journal of Public Economics, 81, 99-115. https://doi.org/10.1016/S0047-2727(00)00130-4

Hermalin, B. E., \& Weisbach, M. S. (1998). Endogenously Chosen Boards of Directors and Their Monitoring of the CEO. American Economic Review, 96-118.

Iwasaki, I. (2008). The Determinants of Board Composition in a Transforming Economy: Evidence from Russia. Journal of Corporate Finance, 14, 532-549.

https://doi.org/10.1016/j.jcorpfin.2008.09.005

Jiang, G., Lee, C. M. C., \& Yue, H. (2010). Tunneling through Intercorporate Loans: The China Experience. Journal of Financial Economics, 98, 1-20.

https://doi.org/10.1016/j.jfineco.2010.05.002

Lease, R. C., McConnell, J. J., \& Mikkelson, W. H. (1983). The Market Value of Control in Publicly-Traded Corporations. Journal of Financial Economics, 11, 439-471. https://doi.org/10.1016/0304-405X(83)90019-3

Linck, J. S., Netter, J. M., \& Yang, T. (2008). The Determinants of Board Structure. Journal of Financial Economics, 87, 308-328. https://doi.org/10.1016/j.jfineco.2007.03.004

Liu, H., Tang, S., \& Lou, J. (2012). Independent Directors: Supervision or Consultation?-Research on the Influence of Independent Directors on Enterprise Credit Financing under the Background of Bank. Management World, No. 1, 148-163+176.

Meckling, W. H., \& Jensen, M. C. (1976). Theory of the Firm: Managerial Behavior, Agency Costs and Ownership Structure. Journal of Financial Economics, 3, 305-360. https://doi.org/10.1016/0304-405X(76)90026-X

Villalonga, B., \& Amit, R. (2006). How Do Family Ownership, Control and Management Affect Firm Value? Journal of Financial Economics, 80, 385-417. https://doi.org/10.1016/j.jfineco.2004.12.005

Wang, B. (2007). Do Independent Directors Supervise?-From the Perspective of Earnings Quality of Listed Companies in China. Financial Research, 1, 109-121.

Weisbach, M. S. (1988). Outside Directors and CEO Turnover. Journal of Financial Economics, 20, 431-460. https://doi.org/10.1016/0304-405X(88)90053-0

Xiao, W. J., Wang, Z. W., \& Duan, Y. (2009). The Impact of Independent Directors on 
Corporate Performance in the Presence of Major Shareholders: An Endogenous Perspective. Nankai Management Review, 2, 90-97.

Zheng, Z. G., Hu, X. J., \& Huang, J. C. (2019). Over-Appointment of Directors, Opportunism of Major Shareholders and Voting Behavior of Directors. China's Industrial Economy, No. 10, 155-174. 